\title{
Isoproterenol Triggers ROS/P53/S100-A9 Positive Feedback to Aggravate Myocardial Damage Associated with Complement Activation
}

Simiao Fan ${ }^{1, a}$, Huan Zhao ${ }^{1, a}$, Yuechen Liu ${ }^{1, a}$, Pengjie Zhang ${ }^{1, a}$, Yuming Wang ${ }^{1}$, Yanyan

$\mathrm{Xu}^{1}$, Kun $\mathrm{Gu}^{1}$, Tianpu Zhang ${ }^{1}$, Jiao $\mathrm{Yu}^{2}$, Wulin $\mathrm{Qi}^{2}$, Yubo $\mathrm{Li}^{1 *}$, Yanjun Zhang ${ }^{1 *}$

${ }^{1}$ Note: Tianjin University of Traditional Chinese Medicine, No. 10, Poyang Lake Road, West Zone, Tuanbo New City, Jinghai District, Tianjin 301600, China.

${ }^{2}$ Note: Jingjie PTM Biolabs (Hangzhou) Co. Ltd, Hangzhou, P. R.310018 China

${ }^{a}$ Note:These authors contributed equally to this work.

\section{*Corresponding authors:}

Yubo Li, Yanjun Zhang.

Tianjin University of Traditional Chinese Medicine, No. 10, Poyang Lake Road, West Zone, Tuanbo New City, Jinghai District, Tianjin 301600, China.

E-mail: yaowufenxi001@sina.com (Yubo Li), tianjin_tcm001@sina.com (Yanjun Zhang).

Tel and Fax number: +86-22-59596261. 


\section{Supplementary materials}

\section{Supplementary Figures}

A

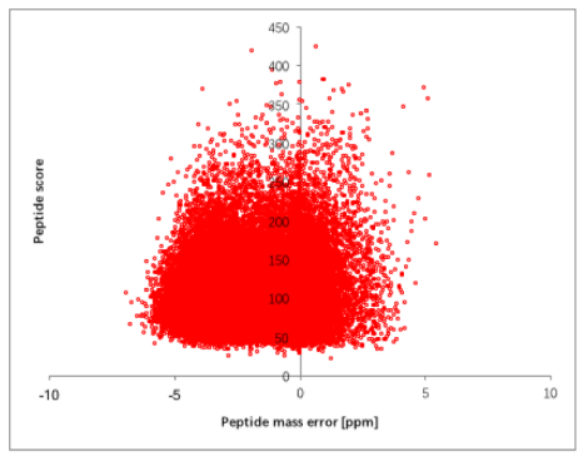

B

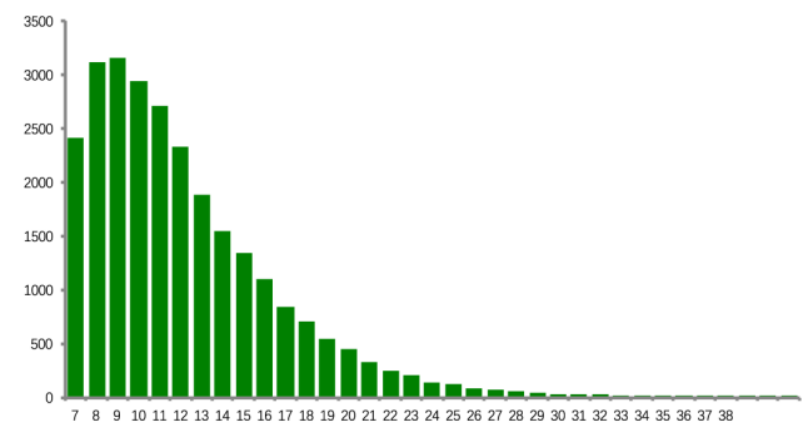

$\mathrm{C}$
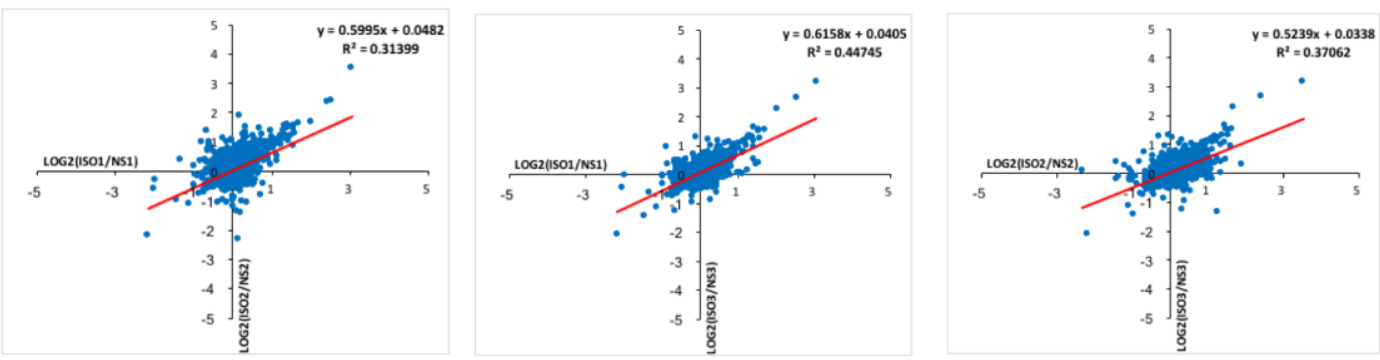

Fig. S1 (A) Identification of mass shift profile of peptides (B) Identification of length distribution of peptides (C) Repeatability between samples (NS: blank group, ISO: isoproterenol group)

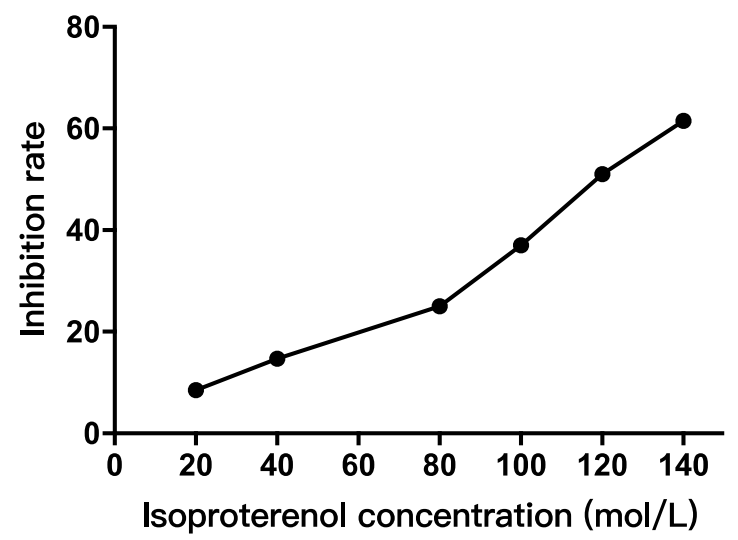

Fig. S2 Inhibition rate of different concentrations of ISO on $\mathrm{H} 9 \mathrm{c} 2$ cells 


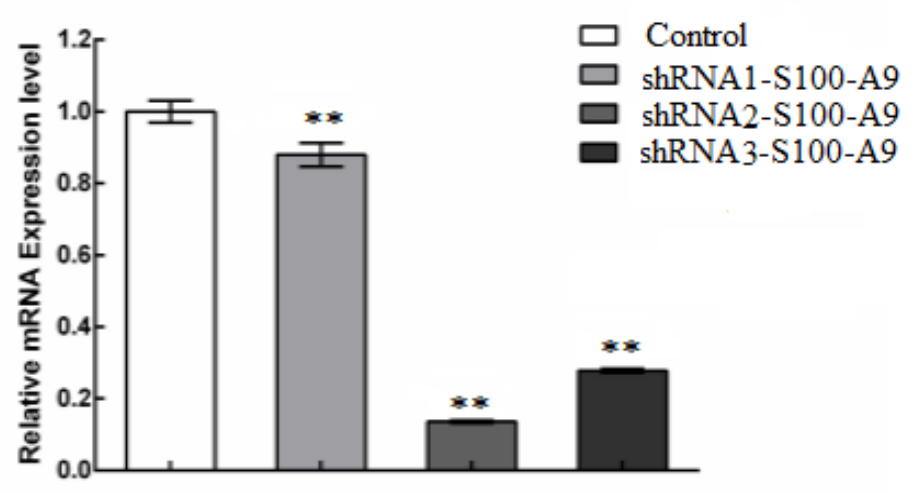

Fig. S3 qPCR method to verify the interference efficiency of three interference plasmids pSilencer2.1-U6/shRNA-S100-A9 (**: compared with Control group, $p<0.01$; *: compared with NS group, $p<0.05$ )

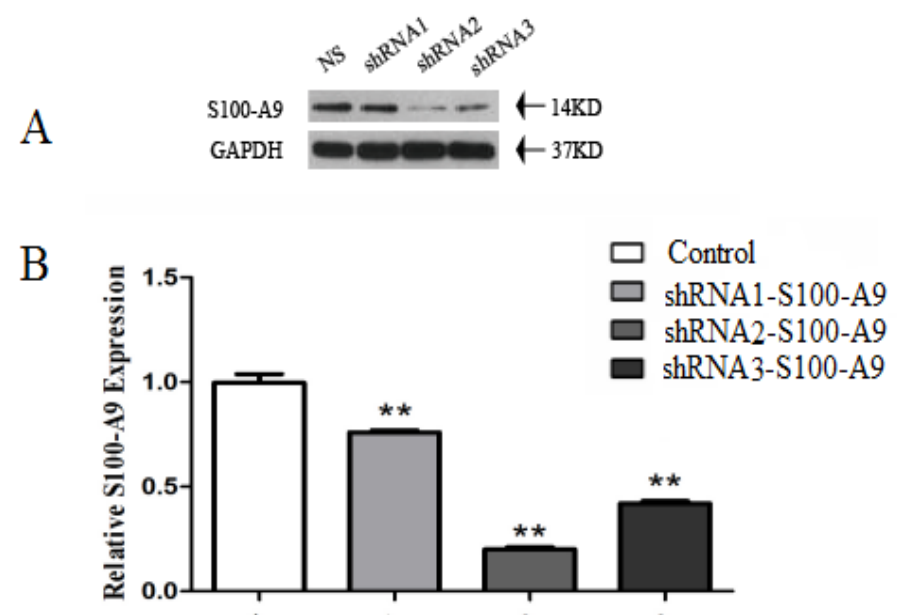

Fig. S4 Western blot analysis of the interference efficiency of pSilencer2.1-U6/shRNA-S100-A9 (A: S100-A9 protein expression band diagram; B: S100-A9 protein expression histogram. **: compared with Control group, $p<0.01$.) 


\section{Supplementary Methods}

\section{Pretreatment of tissue samples before analysis}

Pretreatment of metabonomics analysis: heart tissue was cut and mixed evenly, and $200 \mu \mathrm{L}$ precooled physiological saline was added to every $100 \mathrm{mg}$ to homogenize. Take $100 \mu \mathrm{L}$ of homogenate, add $1000 \mu \mathrm{L}$ of methanol, vortex and mix uniformly for $1 \mathrm{~min}$, ultrasonic in ice-water bath for $10 \mathrm{~min}$, centrifuge at $13000 \mathrm{rpm}$ at $4^{\circ} \mathrm{C}$ for $10 \mathrm{~min}$, suck up $1 \mathrm{~mL}$ of supernatant, blow dry under $\mathrm{N}_{2}$ flow, re-dissolve with $100 \mu \mathrm{L}$ of pure methanol during the test, vortex and centrifuge, and take $5 \mu \mathrm{L}$ of supernatant for UPLC/Q-TOF-MS analysis.

Preparation of QC samples: in addition, $10 \mu 1$ of tissue samples were sucked into the centrifuge tube, mixed and swirled for $1 \mathrm{~min}$, centrifuged at $13000 \mathrm{rpm}$ at $4{ }^{\circ} \mathrm{C}$ for $10 \mathrm{~min}$, and the supernatant was sucked to prepare QC samples by the same operation method.

Extraction of myocardial protein: the myocardial tissue was taken out of liquid nitrogen, and the same amount of myocardial tissue was taken from each group to the mortar precooled by liquid nitrogen, and then liquid nitrogen was added and ground into powder. Samples of each group were added with lysis buffer (8M urea and $1 \%$ protease inhibitor) with 4 times volume of powder, and then ultrasonically lysed with ultrasonic instrument to completely break nucleic acid. Then, at $4{ }^{\circ} \mathrm{C}, 12000 \mathrm{~g}$, centrifuge for 10 min, remove cell debris, collect supernatant into a new centrifuge tube, and use BCA (bicinchoninic acid) kit to measure protein concentration.

\section{Metabolomics analysis conditions of tissue sample}

Chromatographic conditions: Column: ACQUITY UPLC BEH C18 $(2.1 \times 100 \mathrm{~mm}$, $1.7 \mu \mathrm{m}$ ); Flow rate: $0.3 \mathrm{~mL} / \mathrm{min}$; column temperature: $40^{\circ} \mathrm{C}$; injection volume: $5 \mu \mathrm{L}$; 
gradient elution conditions: $0 \sim 0.5 \mathrm{~min}, 1 \% \mathrm{~B} ; 0.5 \sim 2 \mathrm{~min}, 1 \%-50 \% \mathrm{~B} ; 2 \sim 9 \mathrm{~min}$, 50\%-99\% B; 9 10 min, 99\%; 10 10.5 min, 99\%-1\% B; 10.5 12 min, 1\% B.

Mass spectrometry conditions: mass spectrometry detection was performed in positive and negative ion mode using an electrospray ionization source (ESI source). High purity $\mathrm{N}_{2}$ was used as the auxiliary spray ionization and desolvation gas; dry gas flow rate: $10 \mathrm{~mL} / \mathrm{min} ; \mathrm{N}_{2}$ temperature: $350{ }^{\circ} \mathrm{C}$; atomization gas pressure: $310 \mathrm{kPa}$; desolvent nitrogen flow rate: $600 \mathrm{~L} / \mathrm{h}$; cone hole backflushing nitrogen: $50 \mathrm{~L} / \mathrm{h}$; Capillary ionization voltage: $2.1 \mathrm{kV}$; quadrupole scanning range: m/z 50-1000.

\section{Proteomics analysis conditions of tissue sample}

Chromatographic conditions: peptide fragments were dissolved in $0.1 \%$ formic acid aqueous solution of mobile phase a of liquid chromatography, and then separated by EASY-nLC 1000 ultra-high performance liquid system. The mobile phase $\mathrm{A}$ is an aqueous solution containing $0.1 \%$ formic acid; The mobile phase $\mathrm{B}$ is acetonitrile solution containing $0.1 \%$ formic acid. Liquid phase gradient setting: 0 60 min, 6\%-20\% B; 60 80 min, 20\%-30\% B; 80 86 $\mathrm{min}, 30 \%-80 \% \mathrm{~B} ; 86 \sim 90 \mathrm{~min}, 80 \% \mathrm{~B}$, flow rate maintained at $350 \mathrm{~nL} / \mathrm{min}$.

Mass spectrometry conditions: the peptide was separated by ultra-high performance liquid phase system, then injected into NSI ion source for ionization and then analyzed by Orbitrap Fusion Lumos mass spectrometry. Ion source voltage: $2.4 \mathrm{kV}$; scanning range of primary mass spectrometry: $350-1550 \mathrm{~m} / \mathrm{z}$; scan resolution: 60,000; The scanning range of secondary mass spectrometry is fixed starting point: $100 \mathrm{~m} / \mathrm{z}$; and Orbitrap scan resolution: 30,000; Data acquisition mode uses data dependent scanning (DDA) program; 
automatic gain control (AGC): 5E4; signal threshold: 5000 ions/s; maximum injection time: $100 \mathrm{~ms}$; and dynamic exclusion time of tandem mass spectrometry scanning: 30s.

\section{Flow cytometry to detect the level of ROS}

H9c2 cells in a good growth state and in log phase were selected, digested in $0.1 \%$ trypsin, resuspended in DMEM culture medium, and then counted. Next, $1.5 \times 104$ cells per well were added to a 6-well plate and cultured in a cell culture incubator at 5\% $\mathrm{CO} 2$ and $37^{\circ} \mathrm{C}$ for 24 hours (to promote cell adherence). After 24 hours, the cells were washed 3 times with $1 \times \mathrm{PBS}$ and different treatments were carried out according to the experiment, after which cultivation was continued for an additional 12 hours. After 12 hours, DCFH-DA was diluted 1:1000 with serum-free medium to give a final concentration of $10 \mu \mathrm{mol} / \mathrm{L}$. The cell culture medium was then removed and $1 \mathrm{ml}$ of diluted DCFH-DA was added to the cells, which were then incubated in a $37^{\circ} \mathrm{C}$ cell incubator for $20 \mathrm{~min}$. Next, the cells were washed three times with serum-free cell culture medium to completely remove the residual DCFH-DA that did not enter the cells. Then, $300 \mu \mathrm{l}$ of $0.1 \%$ trypsin-digested cells were added to each well, the cells were collected with serum-free medium and centrifuged at $1000 \mathrm{rpm} / \mathrm{min}$ for $3 \mathrm{~min}$. The cells were resuspended in $300 \mu 1$ of serum-free medium, and the fluorescence intensity of each group, that is, the intensity of intracellular ROS, was measured by flow cytometry. Analysis was performed using the FlowJo software. The average FL1-A amount (Mean FITC-A) can be used as a quantitative basis for ROS intensity.

\section{Interference plasmid cell transfection}

The following plasmids were used in the transfection experiments: pSilencer2.1-U6,

pSilencer2.1-U6/shRNA1-S100-A9, pSilencer2.1-U6/shRNA2-S100-A9, and 
pSilencer2.1-U6/shRNA3-S100-A9. Two millilitres of H9c2 cell suspension (containing $1.0 \times 106$ cells) was inoculated into 6 -well plates with 3 replicate wells in each group, and the cells were cultured in a $37{ }^{\circ} \mathrm{C}$, contained $5 \% \mathrm{CO}_{2}$ cell incubator for 24 hours (to promote complete cell adherence). Half an hour before transfection, the medium was removed and replaced with $500 \mu \mathrm{l}$ Opti-MEM serum-free medium. The transfection mixture (amount of plasmid per transfection per well) was prepared as two solutions, solution A and B. Solution A consisted of $2 \mu \mathrm{g}$ plasmid DNA added to Opti-MEM serum-free medium to a final volume of $50 \mu 1$ and gently mixed, and solution B contained $2 \mu 1$ of gently mixed Lipofectamine 2000 in Opti-MEM serum-free medium to a final volume of $50 \mu 1$ that was gently mixed and incubated at room temperature for 5 min. Solutions A and B were combined, gently mixed, and incubated at room temperature for $20 \mathrm{~min}$. The mixture was slowly added dropwise to the above culture flask and mixed well. The cells were then incubated in a $5 \% \mathrm{CO}_{2}$ incubator at $37^{\circ} \mathrm{C}$. After 6 hours, the supernatant was aspirated and $2 \mathrm{ml}$ of normal medium was added for incubation for an additional 48 hours. After 48 hours, the 3 complexes were added. One well was selected for proteolysis and two wells were supplemented with Trizol for RNA extraction.

\section{Extraction of Total RNA}

Two duplicate wells were selected from each group. Each well was washed twice with PBS before $0.5 \mathrm{ml}$ Trizol was added and the wells were cooled on ice for 5-10 min. The wells were shaken 3 times, making sure the cell surface was is in complete contact with Trizol, and then the cell/Trizol solution was transferred into a $1.5 \mathrm{~mL}$ EP. Next, $200 \mu 1$ of pre-cooled chloroform was added per $1 \mathrm{ml}$ of Trizol, the sample was mixed thoroughly by inversion, and placed on ice for $5 \mathrm{~min}$. The sample was then centrifuged at 
$12000 \mathrm{rpm}$ for $1 \mathrm{~min}$ at $4{ }^{\circ} \mathrm{C}$, after which the supernatant was carefully aspirated into a new EP tube, Then, $1 \mathrm{~mL}(\mathrm{v}: \mathrm{v} / 1: 5)$ of pre-cooled absolute ethanol was added to the tube and then sample was mixed and allowed to stand at $-80{ }^{\circ} \mathrm{C}$ for more than $30 \mathrm{~min}$, followed by centrifugation at $12000 \mathrm{rpm}$ at $4{ }^{\circ} \mathrm{C}$ for $30 \mathrm{~min}$. After precipitating the RNA, the supernatant was carefully discarded, $1 \mathrm{ml}$ of pre-cooled $80 \%$ ethanol was added, the pellet was gently bounced, and the sample was centrifuged at $12000 \mathrm{rpm}$ at $10{ }^{\circ} \mathrm{C}$ for 10 min. The supernatant was then completely discarded, the tube lid was opened, and the tube was allowed to stand at room temperature for $5 \mathrm{~min}$. Each tube was mixed with 20 $\mu \mathrm{L}$ of EPC water for 15 min to dissolve the isolated RNA; $1 \mu$ l of RNA sample was taken for quantification and electrophoresis and the remaining RNA was stored at $-80^{\circ} \mathrm{C}$.

\section{Fluorescence quantitative PCR amplification experiment}

The primer sequences are as follows:

The reaction system contained $10.0 \mu \mathrm{L} 2 \times$ SYBR Premix Ex Taq, $1.0 \mu \mathrm{L}$ PCR S Primer $(5 \mathrm{pmol} / \mu \mathrm{l}, 1.0 \mu \mathrm{L}$ PCR AS Primer $(5 \mathrm{pmol} / \mu \mathrm{L}), 1.0 \mu \mathrm{L}$ template (RT product cDNA), and 7.0 $\mu \mathrm{L}$ DDW for a total reaction volume of $20 \mu \mathrm{L}$.

The reaction temperature cycling conditions were as follows: $94{ }^{\circ} \mathrm{C}$ for $4 \mathrm{~min}$, followed by 40 cycles of $94{ }^{\circ} \mathrm{C}$ for $30 \mathrm{~s}, 56{ }^{\circ} \mathrm{C}$ for $30 \mathrm{~s}$, and $72{ }^{\circ} \mathrm{C}$ for $30 \mathrm{~s}$. After PCR, the data were analysed and a histogram was drawn. 


\section{Supplementary Table}

Table S1. Potential biomarker information of cardiac toxicity

\begin{tabular}{|c|c|c|c|c|c|c|c|}
\hline No. & $\mathbf{t}_{\mathrm{R}}(\mathrm{min})$ & Obsd m/z & ppm & Metabolite & Formula & $\begin{array}{c}\text { Fold Change } \\
\text { (ISO/NS) }\end{array}$ & $\begin{array}{c}\text { Change trend } \\
\text { (ISO/NS) }\end{array}$ \\
\hline 1 & 0.81 & 204.1239 & -1.47 & Acetyl carnitine & $\mathrm{C}_{9} \mathrm{H}_{17} \mathrm{NO}_{4}$ & 0.65 & $\downarrow * *$ \\
\hline 2 & 2.33 & 585.292 & -1.50 & Glucoside & $\mathrm{C}_{29} \mathrm{H}_{44} \mathrm{O}_{12}$ & 0.22 & $\downarrow *$ \\
\hline 3 & 0.80 & 118.0873 & -4.23 & Valine & $\mathrm{C}_{5} \mathrm{H}_{11} \mathrm{NO}_{2}$ & 1.85 & $\uparrow^{*}$ \\
\hline 4 & 0.78 & 146.0451 & 1.37 & Glutamate & $\mathrm{C}_{5} \mathrm{H}_{9} \mathrm{NO}_{4}$ & 0.75 & $\downarrow *$ \\
\hline 5 & 0.79 & 102.0555 & 0.00 & Dimethyl glycine & $\mathrm{C}_{4} \mathrm{H}_{9} \mathrm{NO}_{2}$ & 0.69 & $\downarrow *$ \\
\hline 6 & 0.80 & 169.0591 & -1.18 & Glutamine & $\mathrm{C}_{5} \mathrm{H}_{10} \mathrm{~N}_{2} \mathrm{O}_{3}$ & 0.63 & $\downarrow^{*}$ \\
\hline 7 & 5.07 & 198.0534 & -0.50 & 2-Methylbutyrylglycine & $\mathrm{C}_{7} \mathrm{H}_{13} \mathrm{NO}_{3}$ & 0.63 & $\downarrow^{*}$ \\
\hline 8 & 5.30 & 558.2972 & -1.79 & LysoPC(18:2) & $\mathrm{C}_{26} \mathrm{H}_{50} \mathrm{NO}_{7} \mathrm{P}$ & 0.47 & $\downarrow * *$ \\
\hline 9 & 5.52 & 546.353 & 1.10 & LysoPC(18:0) & $\mathrm{C}_{26} \mathrm{H}_{54} \mathrm{NO}_{7} \mathrm{P}$ & 0.59 & $\downarrow *$ \\
\hline 10 & 1.98 & 206.1388 & 1.94 & Panthenol & $\mathrm{C}_{9} \mathrm{H}_{19} \mathrm{NO}_{4}$ & 0.32 & $\downarrow * *$ \\
\hline 11 & 1.84 & 298.069 & 0.67 & D-4'- phosphate pantothenate & $\mathrm{C}_{9} \mathrm{H}_{18} \mathrm{NO}_{8} \mathrm{P}$ & 2.05 & $\uparrow *$ \\
\hline 12 & 8.16 & 277.1217 & 1.80 & Pantomide & $\mathrm{C}_{11} \mathrm{H}_{22} \mathrm{~N}_{2} \mathrm{O}_{4} \mathrm{~S}$ & 0.41 & $\downarrow^{*}$ \\
\hline 13 & 1.83 & 284.0998 & -1.06 & 8-Hydroxydeoxyguanosine & $\mathrm{C}_{10} \mathrm{H}_{13} \mathrm{~N}_{5} \mathrm{O}_{5}$ & 0.66 & $\downarrow^{*}$ \\
\hline 14 & 1.83 & 152.0578 & -3.94 & Guanine & $\mathrm{C}_{5} \mathrm{H}_{5} \mathrm{~N}_{5} \mathrm{O}$ & 0.77 & $\downarrow *$ \\
\hline 15 & 0.80 & 124.0066 & 1.61 & Taurine & $\mathrm{C}_{2} \mathrm{H}_{7} \mathrm{NO}_{3} \mathrm{~S}$ & 0.76 & $\downarrow^{*}$ \\
\hline 16 & 0.70 & 207.0517 & -1.93 & Lipoic acid & $\mathrm{C}_{8} \mathrm{H}_{14} \mathrm{O}_{2} \mathrm{~S}_{2}$ & 0.55 & $\downarrow * *$ \\
\hline 17 & 5.44 & 249.1842 & -4.82 & Nutmeg oleic acid & $\mathrm{C}_{14} \mathrm{H}_{26} \mathrm{O}_{2}$ & 0.61 & $\downarrow^{*}$ \\
\hline 18 & 4.92 & 241.1798 & 2.49 & 3-Oxotetradecanoic acid & $\mathrm{C}_{14} \mathrm{H}_{26} \mathrm{O}_{3}$ & 0.14 & $\downarrow * *$ \\
\hline 19 & 2.86 & 159.1015 & 3.77 & Hydroxyoctanoic acid & $\mathrm{C}_{8} \mathrm{H}_{16} \mathrm{O}_{3}$ & 0.37 & $\downarrow * *$ \\
\hline 20 & 3.79 & 215.1642 & 2.32 & 3-Hydroxydodecanoic acid & $\mathrm{C}_{12} \mathrm{H}_{24} \mathrm{O}_{3}$ & 0.32 & $\downarrow * *$ \\
\hline 21 & 5.54 & 255.2321 & 1.17 & Palmitic acid & $\mathrm{C}_{16} \mathrm{H}_{32} \mathrm{O}_{2}$ & 1.62 & $\uparrow *$ \\
\hline 22 & 6.84 & 283.2635 & 0.71 & Stearic acid & $\mathrm{C}_{18} \mathrm{H}_{36} \mathrm{O}_{2}$ & 1.97 & $\uparrow^{*}$ \\
\hline
\end{tabular}


